\title{
MENINGKATKAN KETERAMPILAN PROSES SAINS ANAK USIA DINI MELALUI AKTIVITAS BERKEBUN
}

\author{
Mirawati $^{1}$ \\ Rini Nugraha ${ }^{2}$ \\ 'Universitas Muhammadiyah Tasikmalaya \\ ${ }^{2}$ TK Laboratorium UPI \\ mirapaud@gmail.com \\ nugraha.rini@gmail.com
}

\begin{abstract}
Abstrak
Artikel ini membahas tentang penelitian terkait penerapan aktivitas berkebun sebagai upaya meningkatkan keterampilan proses sains bagi anak usia dini di TK Lab. UPI. Penelitian ini bertujuan untuk melihat kondisi awal keterampilan proses sains anak usia dini sebelum penerapan aktivitas berkebun, gambaran pelaksanaan aktivitas berkebun di TK Lab. UPI, serta peningkatan keterampilan proses sains anak setelah penerapan aktivitas berkebun. Penelitian ini menggunakan metode penelitian tindakan kelas yang dilaksanakan TK Lab. UPI. Pengumpulan data dilakukan melalui observasi, wawancara dan dokumentasi. Analisis data yang digunakan adalah analisis data kualitatif dengan teknik thematic analysis. Hasil dalam penelitian ini menunjukkan bahwa aktivitas berkebun mampu memberikan kontribusi positif terhadap peningkatan keterampilan proses sains di TK Lab. UPI. Berkebun juga memberikan kontribusi terhadap perkembangan fisik-motorik, bahasa, kognitif, sosial-emosi dan juga moral-keagamaan anak, sehingga dapat disimpulkan bahwa kegiatan berkebun mampu memberikan hasil positif terhadap berbagai aspek perkembangan anak secara terpadu.
\end{abstract}

Kata Kunci: Berkebun, Keterampilan Proses, Sains

\begin{abstract}
This paper discusses about research related to the implementation of gardening activities as an effort to improve the science process skills for early childhood in TK Lab. UPI. This study aims to examine the initial conditions of early childhood science process skills before the implementation of gardening activities, description of the implementation of gardening activities in TK Lab. UPI, as well as the improvement of children's science process skills after the implementation of gardening activities. This research uses action research method that is implemented in TK Lab. UPI. Data collection is done through observation, interview and documentation. Data analysis used is qualitative data analysis with thematic analysis technique. The results in this study indicate that the activity of gardening is able to contribute positively to the improvement of science process skills in TK Lab. UPI. Gardening also contributes to the physical development, language, cognitive, social-emotional and also moral-religious for children, so it can be concluded that gardening activities can provide positive results on various aspects of child development in an integrated manner.
\end{abstract}

Keywords: Gardening, Process Skills, Science 


\section{Pendahuluan}

Pembelajaran sains, termasuk pengenalan konsep kealaman bagi anak merupakan suatu upaya membantu anak untuk menemukan konsep dan proses tertentu dalam kehidupan, dengan kata lain pembelajaran sains bagi anak pada hakikatnya dijadikan sebagai media yang digunakan untuk menstimulasi aspek perkembangan dan memaksimalkan potensi yang ada dalam diri anak. Hal tersebut senada dengan ungkapan Havu-Nuutinen (Gross, 2012: 1-2) sebagai berikut:

"Science education is a process of conceptual change in which children reorganize their existing knowledge in order to understand concept and process.. more completely"

Lebih lanjut, Trundle (2009: 1) menyatakan bahwa pembelajaran sains pada pendidikan anak usia dini memberikan manfaat yang sangat besar untuk berbagai aspek perkembangan anak, sehingga para peneliti menekankan betapa pentingnya pembelajaran sains yang dimulai sejak dini. Eshach and Fried (Trundle, 2009) menyatakan bahwa pembelajaran sains bagi anak usia dini dapat memberikan pengalaman positif bagi anak yang membantu dirinya untuk mengembangkan pemahaman tentang suatu konsep sains, mengembangkan kemampuan berpikir, menanamkan sikap yang positif, dan memberikan landasan yang kuat untuk pengembangan konsep sains di jenjang pendidikan selanjutnya.

Uraian di atas menyiratkan tentang pentingnya pengalaman belajar sains bagi anak di berbagai jenjang sekolah, termasuk di jenjang pra sekolah dan sekolah dasar. Sayangnya, pembelajaran sains di kedua jenjang tersebut terkadang pelaksanaannya masih belum optimal, biasanya terbatas pada pemberian kegiatan praktik langsung, demonstrasi dan seringkali terpaku pada buku pelajaran atau lembar kerja siswa. Konsep yang diajarkan pada anak pun cenderung kaku dan kurang disesuaikan dengan tahapan perkembangan anak, sehingga cenderung memaksakan anak untuk memahami konsep sains tersebut. Padahal, pada dasarnya pembelajaran yang baik bagi anak adalah pembelajaran yang mampu memberikan pengalaman secara langsung dan mampu menstimulasi perkembangan anak secara terpadu, bukan hanya untuk pengembangan salah satu aspek saja (Suyadi \& Ulfah, 2013; Santrock, 2007).

Tujuan mendasar dari pembelajaran sains bagi anak adalah mengembangkan aspek perkembangan dan potensi yang dimiliki anak. Selain itu pembelajaran sains juga ditujukan untuk mengembangkan individu agar mengenal ruang lingkup sains itu sendiri serta mampu menggunakan aspek-aspek fundamental dalam memecahkan masalah yang dihadapinya. Jadi, fokus program pengembangan pembelajaran sains hendaklah ditujukan untuk memupuk 
pemahaman, minat dan penghargaan anak didik terhadap dunia di mana mereka hidup yaitu alam semesta (Sumaji, 1988). Leeper (Nugraha, 2008) juga menyampaikan bahwa pengembangan pembelajarn sains pada anak hendaklah di tujukan agar anak-anak memiliki kemampuan memecahkan masalah yang dihadapinya melalui penggunaan metode sains, sehingga anak-anak terbantu dan menjadi terampil dalam menyelesaikan berbagai hal yang dihadapinya, memiliki sikap-sikap ilmiah dalam mendapatkan pengetahuan atau informasi ilmiah, termasuk juga memiliki keterampilan proses sains.

Menurut Dahar (1996), keterampilan proses sains adalah kemampuan individu untuk menerapkan metode ilmiah dalam memahami, mengembangkan dan menemukan ilmu pengetahuan. Keterampilan ini sangat penting bagi setiap individu sebagai bekal untuk menggunakan metode ilmiah dalam mengembangkan sains serta diharapkan memperoleh pengetahuan baru atau mengembangkan pengetahuan yang telah dimiliki. Adapun keterampilan proses sains yang ingin di tingkatkan di TK Lab. UPI adalah keterampilan proses sains dasar bagi anak yang meliputi kemampuan mengamati, membandingkan, mengklasifikasikan/ mengelompokkan, mengukur dan mengomunikasikan (Charlesworth, K., \& Lind, 2010). Keterampilan proses sains tersebut belum terlihat dalam perkembangan anak di TK Lab. UPI, sehingga memerlukan suatu upaya yang tepat untuk mengoptimalkannya. Salah satu aktivitas yang diasumsikan mampu memberikan pengalaman belajar sains secara terpadu pada anak, sehingga mampu memberikan stimulasi positif terhadap keterampilan proses sains adalah kegiatan berkebun. Berdasarkan berbagai literatur dan penelitian terdahulu, kegiatan berkebun memiliki banyak manfaat bagi pencapaian berbagai aspek perkembangan anak, sehingga program tersebut bisa dijadikan sebagai alternatif pembelajaran sains yang bermakna untuk anak.

Berdasarkan uraian di atas, penulis bermaksud untuk menguraikan lebih lanjut terkait dengan penerapan kegiatan berkebun untuk meningkatkan keterampilan proses sains anak usia dini di TK Lab. UPI.

\section{Landasan Teori}

\section{Urgensi Pembelajaran Sains Bagi Anak}

Pembelajaran sains bagi anak bukanlah aktivitas pengenalan dan pengajaran terkait konsep-konsep sains tertentu pada anak semata, namun merupakan suatu upaya yang digunakan untuk menstimulasi aspek perkembangan dan memaksimalkan potensi yang ada dalam diri anak (Gross, 2012). Dengan kata lain, daam proses pembelajaran sains, bukan 
konsep sains yang ditekankan untuk dipahami oleh anak, namun lebih mengarah kepada bagaimana pembelajaran sains tersebut mampu menjadi alat untuk menstimulasi berbagai aspek perkembangan anak sejak dini.

Menurut Wenham (Gross, 2012: 1) 'science is a way of exploring and investigating the world around us... not only a way of knowing; it is.... a way of doing'. Berdasarkan pendapat Wenham tersebut, dapat diartikan bahwa sains itu bukan hanya sekedar pengetahuan saja, tapi proses dan juga tindakan yang kita lakukan dalam mencapai pengetahuan tersebut. Selain itu, Worms, Shadow and Whirlpools (Halverson, 2007) menyatakan terkait kayanya manfaat dari pembelajaran sains untuk anak antara lain mampu memupuk rasa percaya diri anak di dalam lingkunganya, memberikan pengalaman penting secara langsung pada anak, mengembangkan konsep dasar pengetahuan alam, meningkatkan kemampuan mengamati, memperoleh kesempatan untuk menggunakan material yang biasa digunakan dalam pembelajaran sains, sehingga anak mulai terbiasa sejak dini, memperoleh bantuan dalam memecahkan masalah, mendapat kesempatan untuk menstimulasikan rasa keingintahuan mereka dan mendapatkan kesempatan untuk bereksplorasi, mengembangkan kemampuan sensori, fisik, intelektual, emosional, spiritual, dan sosial, serta mengembangkan kemampuan berbahasa melalui penambahahan kosakata ketika anak melakukan kegiatan menanya dan menjawab pertanyaan.

Uraian tersebut di atas menjelaskan tentang begitu banyaknya manfaat yang diperoleh dalam pembelajaran sains bagi anak, sehingga sains mendapatkan posisi yang penting bagi stimulasi tumbuh kembang anak sejak dini.

\section{Tujuan Pembelajaran Sains bagi Anak Usia DIni}

Tujuan pembelajaran sains bagi anak adalah mengembangkan aspek perkembangan dan potensi yang dimiliki anak. Selain itu pembelajaran sains juga ditujukan untuk mengembangkan individu agar mengenal ruang lingkup sains itu sendiri serta mampu menggunakan aspek-aspek fundamental dalam memecahkan masalah yang dihadapinya. Jadi fokus program pengembangan pembelajaran sains hendaklah ditujukan untuk memupuk pemahaman, minat dan penghargaan anak didik terhadap dunia di mana mereka hidup (Sumaji, 1988). Leeper (Nugra, 2008), pada hal-hal di atas secara umum menyampaikan bahwa pengembangan pembelajaran sains pada anak usia dini hendaklah di tujukan untuk merealisasikan empat hal yaitu: 
1. Pengembangkan pembelajaran sains pada anak usia dini ditunjukan agar anak-anak memiliki kemampuan memecahkan masalah yang dihadapinya melalui penggunaan metode sains, sehingga anak-anak terbantu dan menjadi terampil dalam menyelesaikan berbagai hal yang dihadapinya.

2. Pengembangkan pembelajaran sains pada anak usia dini ditunjukan agar anak-anak memiliki sikap-sikap ilmiah. Misalkan tidak cepat-cepat dalam mengambil keputusan, dapat melihat segala sesuatu dari berbagai sudut pandang, berhati-hati terhadap informasi-informasi yang diterimanya.

3. Pengembangkan pembelajaran sains pada anak usia dini ditunjukan agar anak-anak mendapatkan pengetahuan dan informasi ilmiah.

4. Pengembangkan pembelajaran sains pada anak usia dini ditujukan agar anak-anak menjadi lebih berminat dan tertarik untuk menghayati sains yang berbeda dan ditemukan di lingkungan dan alam sekitarnya.

\section{Ruang Lingkup Pembelajaran Sains bagi Anak Usia Dini}

The National Science Education Standards (Bosse, dkk, 2009) menguraikan terkait dengan ruang lingkup pembelajaran sains bagi anak usia dini, antara lain sebagai berikut:

a. Science as Inquiry. Pembelajaran sains sebagai proses yang memberikan kesempatan pada anak untuk memprediksi, menginvestigasi, memperkirakan, mengelompokkan dan mengembangkan kemampuan anak dalam menemukan konsep atau teori.

b. Physical Science. Pembelajaran sains sebagai proses memberikan pengalaman langsung pada anak untuk berinteraksi dengan material sains dan mendorong keberanian/inisiatif anak untuk mengeksplorasi material sains tersebut.

c. Life Science. Pembelajaran sains sebagai proses yang membantu anak untuk dapat memformulasikan pertanyaan-pertanyaan terkait dengan karakteristik benda/makhluk hidup dan tak hidup melalui kegiatan observasi/mengamati.

d. Earth and Space Science. Pembelajaran sains meliputi bahan kajian bumi dan alam semesta (antariksa).

e. Science and Technologi. Pembelajaran sains meliputi keterkaitan antara sains dan teknologi. Dalam hal ini, anak dapat membedakan benda yang terbuat alamiah dan benda buatan manusia. 
f. Science in personal and social perspective. Pembelajaran sains sebagai upaya membawa konsep sains pada perspektif personal dan sosial.

Sedangkan menurut Kellough (1996: 394-401) ruang lingkup pembelajaran sains bagi anak antara lain sebagai berikut:

Tabel 1.1

Ruang Lingkup Pembelajaran Sains bagi Anak

\begin{tabular}{|l|l|l|}
\hline No & \multicolumn{1}{|c|}{ Lingkup } & \multicolumn{1}{c|}{ Deskripsi } \\
\hline 1. & Proses Berpikir & $\begin{array}{l}\text { Lingkup ini meliputi kemampuan anak dalam mengobservasi, } \\
\text { menduga dan mengklasifikasikan }\end{array}$ \\
\hline 2. & Pengembangan Konsep & $\begin{array}{l}\text { Lingkup ini meliputi kemampuan anak dalam membedakan, } \\
\text { mengelompokkan, memberikan label }\end{array}$ \\
\hline 3. & Produk & $\begin{array}{l}\text { Lingkup ini meliputi konten bidang kajian sains antara lain: } \\
\text { a) }\end{array}$ \\
& $\begin{array}{l}\text { Biologi: mempelajari konsep tentang makhluk hidup dan } \\
\text { tak hidup jenis-jenis makhluk hidup di bumi, } \\
\text { mengkategorikan makhluk hidup, memahami ciri atau } \\
\text { karakteristik makhluk hidup, dan memahami proses } \\
\text { kehidupan manusia. Adapun kajian dalam biologi meliputi } \\
\text { tanaman, binatang, manusia, kehidupan (kategori, } \\
\text { karakteristik, adaptasi, siklus kehidupan, dll). }\end{array}$ \\
& $\begin{array}{l}\text { Ilmu Fisik: meiputi kajian tentang astronomi, kimia, } \\
\text { meteorologi dan fisika. }\end{array}$ \\
\hline 4. & Sikap & $\begin{array}{l}\text { Diharapkan diperoleh anak setelah mendapatkan pembelajaran } \\
\text { sains. }\end{array}$ \\
\hline
\end{tabular}

Selain, dua pendapat di atas, ruang lingkup pembelajaran sains untuk anak usia dini menurut Nugraha, (2008: 97-98) antara lain sebagai berikut:

Tabel 1.2

Sains berdasarkan Dimensi Isi bahan Kajian

\begin{tabular}{|l|l|l|}
\hline No & \multicolumn{1}{|c|}{ Kelompok Bahan Kajian } & \multicolumn{1}{|c|}{ Topik Inti } \\
\hline a. & Bumi dan Jagat Raya & $\begin{array}{l}\text { Pengetahuan tentang bintang, matahari dan planet, } \\
\text { Kajian tentang tanah, batuan dan pegunungan, Kajian } \\
\text { tentang Cuaca atau musim. }\end{array}$ \\
\hline b. & Ilmu-ilmu Hayati & $\begin{array}{l}\text { Studi tentang tumbuhan, Studi tentang binatang, Studi } \\
\text { tentang hubungan antara aspek-aspek kehidupan dengan } \\
\text { lingkungan. }\end{array}$ \\
\hline c. & Bidang Kajian Fisika-Kimia & $\begin{array}{l}\text { Studi tentang daya, Studi tentang energy, Studi tentang } \\
\text { rangkaian dan reaksi kimiawi. }\end{array}$ \\
\hline
\end{tabular}


Lingkup sains di atas, terkait dengan bahan kajian sains yang dapat digali oleh anak. adapun sains berdasarkan bidang pengembangan dapat dilihat dalam tabel berikut:

Tabel 1.3

Sains berdasarkan Bidang Pengembangan (Target Kemampuan)

\begin{tabular}{|l|l|l|}
\hline No & Kelompok Bahan Kajian & \multicolumn{1}{|c|}{ Topik Inti } \\
\hline a. & Penguasaan produk sains & $\begin{array}{l}\text { Memahami fakta, Memahami konsep, Memahami prinsip, } \\
\text { hukum dan teori }\end{array}$ \\
\hline b. & Penguasaan proses sains & $\begin{array}{l}\text { Mengamati (observasi), Mengklasifikasikan, Meramalkan, } \\
\text { Menyimpulkan, Mengkomunikasikan, Menggunakan alat } \\
\text { dan pengukuran, Merencanakan penelitian Menerapkan } \\
\text { konsep }\end{array}$ \\
\hline c. & Penguasaan sikap sains & $\begin{array}{l}\text { Rasa tanggung jawab, rasa ingin tahu, disiplin, tekun, Jujur, } \\
\text { terbuka terhadap pendapat lain }\end{array}$ \\
\hline
\end{tabular}

\section{Prinsip Pembelajaran Sains bagi AUD}

Prinsip-prinsip belajar yang dikemukakan oleh Witherington dan Ausuble yang dapat dijadikan sebagai prinsip pembelajaran sains antara lain sebagai berikut (Nugraha, 2008:65-73):

a. Belajar akan berhasil apabila anak melihat tujuan, dan tujuan itu lahir dari dan dekat dengan kehidupan anak.

b. Kegiatan belajar hendaklah dapat merangsang seluruh aspek perkembangan anak, baik jasmani maupun rohani.

c. Lingkungan belajar yang diciptakan hendaklah bermakna dan mengandung arti bagi anak sehingga membentuk pola kelakuan yang berguna bagi anak.

d. Bantuan belajar yang diberikan adalah yang menunjang efektivitas dan efisiensi belajar anak dan dilakukan secara wajar.

e. Adanya upaya pengintegrasian pengalaman belajar sebelumnya dengan pengalaman baru sehingga menjadi satu kesatuan pengalaman yang utuh, tidak mudah lepas atau hilang.

f. Penyajian belajar hendaklah suatu keseluruhan harus lebih dulu dimunculkan kemudian baru menuju sesuatu yang lebih spesifik.

g. Belajar selalu dimulai dengan suatu masalah dan berlangsung sebagai usaha untuk memecahkan masalah tersebut. 
h. Belajar itu berhasil disadari jika telah ditemukan clue (kunci) atau hubungan diantara unsur-unsur dalam masalah itu, sehingga diperoleh insight atau wawasan dan pemahaman.

i. Belajar berlangsung dari yang sederhana meningkat kepada yang lebih kompleks, bergerak dari yang dekat dengan anak hingga yang jauh, serta dari yang konkrit menuju abstrak.

Selain prinsip-prinsip belajar di atas, literatur lain menyatakan beberapa prinsip yang dapat dijadikan sebagai panduan dalam melakasanakan pembelajaran sains bagi anak antara lain sebagai berikut:

a. Prinsip Motivasi. Motivasi adalah daya dorong seseorang untuk melakukan sesuatu kegiatan. Motivasi ada yang berasal dari dalam atau intrinsik dan ada yang timbul akibat rangsangan dari luar atau ekstrinsik. Motivasi intrinsik akan mendorong rasa ingin tahu, keinginan mencoba, mandiri dan ingin maju.

b. Prinsip Latar. Pada hakekatnya anak telah memiliki pengetahuan awal, oleh karena itu dalam pembelajaran guru perlu mengetahui pengetahuan, keterampilan dan pengalaman apa yang telah dimiliki anak sehingga kegiatan belajar mengajar tidak berawal dari suatu kekosongan.

c. Prinsip Menemukan. Pada dasarnya anak memiliki rasa ingin tahu yang besar sehingga potensial untuk mencari guna menemukan sesuatu, oleh karena itu bila diberi kesempatan untuk mengembangkan potensi tersebut anak akan merasa senang atau tidak bosan.

d. Prinsip Belajar Sambil Melakukan (learning by doing). Pengalaman yang diperoleh melalui bekerja merupakan hasil belajar yang tidak mudah terlupakan, oleh karena itu dalam proses belajar mengajar sebaiknya anak diarahkan untuk melakukan kegiatan atau "Learning by doing"

e. Prinsip Belajar sambil Bermain. Bermain merupakan kegiatan yang dapat menimbulkan suasana gembira dan menyenangkan, sehingga akan dapat mendorong anak untuk melibatkan diri dalam proses pembelajaran, oleh karena itu dalam setiap pembelajaran perlu diciptakan suasana yang menyenangkan lewat kegiatan bermain yang kreatif.

f. Prinsip Hubungan Sosial. Dalam beberapa hal kegiatan belajar akan lebih berhasil jika dikerjakan secara berkelompok. Dari kegiatan kelompok anak akan tahu kekurangan 
dan kelebihannya sehingga tumbuh kesadaran perlunya interaksi dan kerja sama dengan orang lain. Pengembangkan pembelajaran sains pada anak usia dini ditunjukan agar anak-anak menjadi lebih berminat dan tertarik untuk menghayati sains yang berbeda dan ditemukan di lingkungan dan alam sekitarnya.

\section{Keterampilan Proses Sains Anak Usia Dini}

Sains sebagai suatu proses yang merupakan cara untuk memperoleh pengetahuan, berhubungan erat dengan kegiatan penelusuran gejala dan fakta-fakta alam yang dilakukan melalui kegiatan laboratorium beserta perangkatnya. Kebenaran sains akan diakui jika penelusurannya berdasar pada kegiatan pengamatan, hipotesis (dugaan), percobaan-percobaan yang ketat dan obyektif, dengan kata lain sains menuntut proses yang dinamis dalam berfikir, pengamatan, eksperimen, menemukan konsep maupun merumuskan berbagai teori. (Asiah, 2012; Nugraha, 2008). Senada dengan pernyataan di atas, keterampilan proses sains adalah kemampuan individu untuk menerapkan metode ilmiah dalam memahami, mengembangkan dan menemukan ilmu pengetahuan (Dahar, 1996). Keterampilan ini sangat penting bagi setiap individu sebagai bekal untuk menggunakan metode ilmiah dalam mengembangkan sains serta diharapkan memperoleh pengetahuan baru atau mengembangkan pengetahuan yang telah dimiliki.

Adapun keterampilan proses sains bagi anak usia dini adalah keterampilan proses sains dasar yang meliputi beberapa kemampuan sebagai berikut (Charlesworth, K., \& Lind, 2010; Asiah, 2012; Nugraha, 2008):

a. Keterampilan mengamati yaitu keterampilan anak dalam melibatkan semua alat indra untuk menyatakan sifat yang dimiliki oleh suatu benda atau objek.

b. Keterampilan membandingkan yaitu keterampilan anak melihat persamaan dan perbedaan dari objek atau benda yang diamati sehingga memperoleh perbandingan.

c. Keterampilan mengklasifikasikan yaitu kemampuan anak dalam mengelompokkan benda atau objek berdasarkan sifat yang diamati dan dibandingkan.

d. Keterampilan mengukur yaitu kemampuan anak mengukur atau menilai objek atau benda.

e. Keterampilan menduga yaitu kemampuan anak memprediksi atau memperkirakan suatu kejadian.

f. Keterampilan mengomunikasikan yaitu kemampuan anak menyampaikan informasi yang diperoleh. 


\section{Berkebun sebagai Aternatif Pembelajaran yang dapat Menstimulasi Keterampilan Proses Sains pada Anak Usia Dini}

Kegiatan berkebun dijadikan sebagai alternatif pembelajaran sains pada anak usia dini karena diasumsikan banyak memiliki manfaat bagi pencapaian aspek perkembangan anak termasuk keterampilan proses sains. Selain mengenalkan tentang pembelajaran sains, berkebun juga memberikan kontribusi terhadap perkembangan fisik-motorik, bahasa, kognitif, sosialemosi dan juga moral-keagamaan anak, sehingga dapat disimpulkan bahwa kegiatan berkebun mampu memberikan hasil positif terhadap berbagai aspek perkembangan anak secara terpadu.

\section{Metode}

Metode yang digunakan ketika penulis melaksanakan penelitian ini adalah metode tindakan dengan desain Kemmis \& Tagart. Teknik pengumpulan data yang digunakan meliputi dua teknik yaitu observasi dan dokumentasi. Data yang diperoleh dilapangan kemudian dianalisis melalui pendekatan kualitatif dengan teknik thematic analysis. Berdasarkan hal tersebut, analisis tematik dalam penelitian ini akan mengacu pada pertanyaan penelitian terkait penerapan kegiatan berkebun untuk meningkatkan keterampilan proses sains anak usia dini 1) Kondisi awal Keterampilan Proses Sains Anak Usia Dini, 2) Bentuk dan Pelaksanaan Kegiatan Berkebun bagi Anak Usia Dini 3) Keterampilan Proses Sains Anak Usia Dini setelah Pelaksanaan Kegiatan Berkebun.Tahapan analisis data yang dilakukan antara lain sebagai berikut (Thomas \& Harden, 2007; Chaedar, 2010):

a. Melakukan Pengodean Data (Coding). Dalam tahap ini penulis mengidentifikasi data dari hasil observasi berupa catatan lapangan dan hasil dokumentasi berdasarkan kode-kode tertentu yang dapat membantu penulis untuk menjawab pertanyaan dalam penelitian ini, yaitu berkaitan dengan kegiatan berkebun dan keterampilan proses sains bagi anak usia dini.

b. Kategorisasi Kode ke dalam Tema. Tahapan yang kedua yang dilakukan oleh penulis adalah melakukan kategorisasi kode-kode yang muncul pada data dengan tema yang didasarkan pada pertanyaan penelitian. 


\section{Hasil Penelitian}

\section{Keterampilan Proses Sains Anak Usia Dini Sebelum Penerapan Kegiatan Berkebun}

Keterampilan proses sains yang dimiliki oleh anak di TK Lab. UPI pada saat obsevasi awal masih belum maksimal. Hasil observasi menunjukkan bahwa keterampilan anak dalam aspek mengamati, membandingkan dan mengklasifikasikan sudah muncul untuk sebagian anak misalnya anak sudah menunjukkan keterampilan dalam menggunakan indranya untuk mengamati suatu objek. Hasil observasi juga menunjukkan sebagian besar anak belum terampil dalam aspek mengukur, menduga dan mengkomunikasikan, misalnya anak belum mampu membuat penilaian dan mengukur suatu benda serta belum mampu menyampaikan hasil informasi yang ia peroleh dalam suatu pembelajaran. Hal tersebut menunjukkan perlunya stimulasi terhadap keterampilan proses sains. Salah satu solusi yang diasumsikan dapat meningkatkan keterampilan proses sains anak dalam penelitian ini adalah kegiatan berkebun.

\section{Bentuk dan Pelaksanaan Kegiatan Berkebun}

Kegiatan berkebun di TK Lab. UPI merupakan salah satu program yang dilakukan untuk meningkatkan keterampilan proses sains anak, terutama terkait tema tanaman. Beberapa tahapan penerapan kegiatan berkebun yang dilaksanakan dalam penelitian ini antara lain sebagai berikut:

a. Perencanaan Kegiatan Berkebun

Pada tahap ini guru mengajak anak merencanakan kegiatan berkebun, membahas apa saja yang dibutuhkan dalam kegiatan berkebun, tanaman apa saja yang kira-kira akan ditanam dan menyiapkan langkah kegiatan berkebun yang akan dilakukan. Perencanaan kegiatan berkebun ini biasanya dimulai dengan membacakan cerita pada anak terkait proses berkebun yang menyenangkan.

b. Pelaksanaan Kegiatan Berkebun

Pada tahap ini guru dan anak melakukan kegiatan berkebun sesuai dengan rencana yang telah disusun sebelumnya. Anak diingatkan kembali terkait dengan langkah-langkah menanam tanaman yang baik oleh guru. Pelaksanan kegiatan berkebun ini memerlukan waktu yang relatif lama dan proses berkebun tidak berhenti setelah anak menanam tanaman saja, namun juga berlanjut pada proses pemeliharaan tanaman yang telah ditanam, misalnya dengan menyiram tanaman secara teratur, memberikan pupuk, dan lain sebagainya. 
c. Tahap Evaluasi Kegiatan Berkebun

Tahap ini dilakukan untuk mereview pelaksanaan kegiatan berkebun yang telah dilakukan oleh anak. Evaluasi juga dilakukan untuk memantau pertumbuhan tanaman yang ada di kebun.

Beberapa contoh pelaksanaan kegiatan berkebun di TK Lab. UPI dalam penelitian ini dapat di lihat dalam tabel dokumentasi sebagai berikut:

Tabel 1.4

Dokumentasi Pelaksanaan Kegiatan Berkebun di TK Lab. UPI

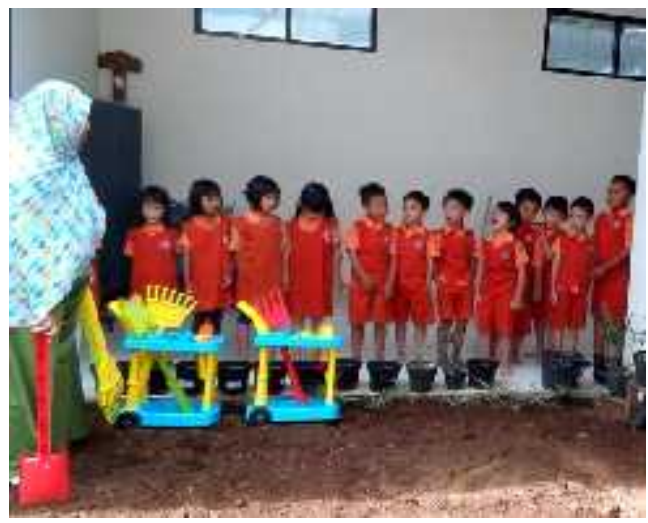

Guru mengajak anak untuk melakukan pengamatan terhadap lahan kebun dan alat-alat berkebun

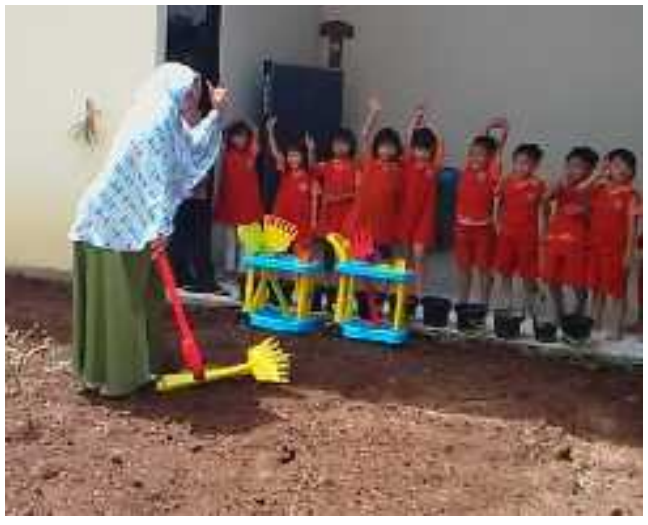

Guru memberi kesempatan pada anak untuk menanya, membandingkan dan mengelompokkan jenis alat berkebun

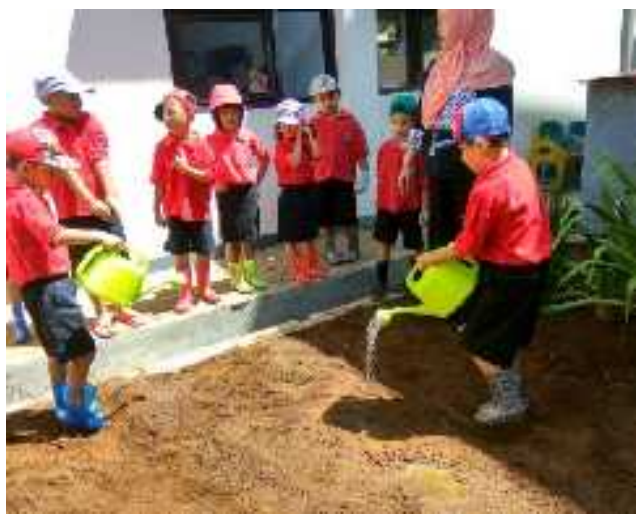

Anak mencoba secara langsung kegiatan menyiram 


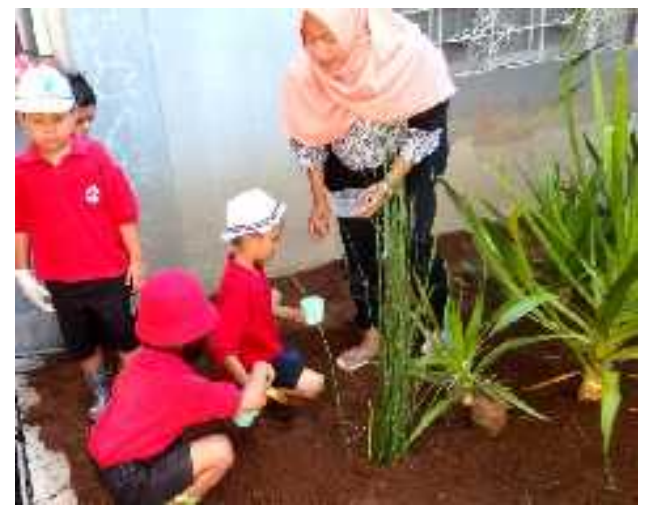

Anak mencoba menanam dalam media pot

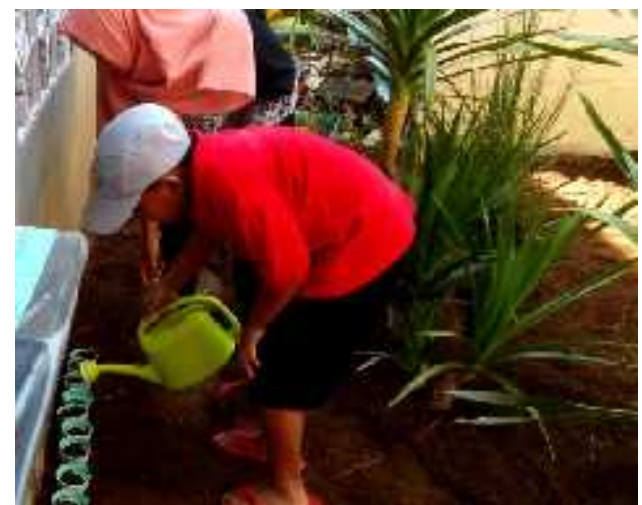

Anak menyiram tanaman dalam pot

\section{Keterampilan Proses Sains Anak Usia Dini Setelah Penerapan Kegiatan Berkebun}

Keterampilan proses sains anak TK Lab. UPI setelah penerapan kegiatan berkebun mengalami peningkatan yang baik. Hasil observasi menunjukkan keterampilan anak dalam proses mengamati misalnya mengamati bibit tanaman, lahan berkebun, alat berkebun dan benda atau objek-objek lainnya terkait dengan kegiatan berkebun yang dilaksanakan di TK Lab. UPI. Keterampilan lainnya yang terstimulasi yaitu kemampuan anak membandingkan. Kegiatan berkebun ini mampu menstimulasi keterampilan anak dalam membuat perbandingan terhadap suatu objek atau benda dan mengklasifikasikannya dalam suatu kelompok yang sama. Selain itu, anak juga mampu membuat penilaian dan prediksi terhadap suatu proses dalam kegiatan berkebun, misalnya ketika anak menyampaikan bahwa ada tanaman yang tumbuh subur karena di siram air dengan cukup (tidak terlalu banyak atau tidak terlalu sedikit) atau ketika anak menyebutkan bahwa kalau tanaman tidak di siram maka tanaman itu bisa layu dan akhirnya mati. Kegiatan berkebun ini juga mampu menstimulasi kemampuan anak menyampaikan informasi yang ia perolah ketika berkebun dalam bentuk cerita.

\section{Analisis Manfaat Pelaksanaan Kegiatan Berkebun}

Beberapa manfaat yang teramati ketika pelaksanaan Kegiatan Berkebun di TK Lab. UPI yang dikaji dengan berbagai teori penunjang antara lain sebagai berikut (Remaklus. U, 2014; Dross, 2012):

a. Menumbuhkan kecintaan anak terhadap alam dengan mengenal tanaman di sekitar anak. 
b. Membuat anak bergerak lebih aktif, karena proses berkebun secara otomatis melibatkan seluruh indra anak, misalnya ketika membantu meletakkan biji, memasukkan tanah ke dalam pot, menyiram tanaman dan lain sebagainya.

c. Anak belajar memahami proses pertumbuhan tanaman. Melalui kegiatan berkebun anak bisa melihat bukti, jika tanaman yang cukup "minum" atau "makan" maka akan tumbuh dengan sehat, begitu pun sebaliknya.

d. Anak dapat mengetahui proses menanam, memelihara, memetik dan memasak tanaman menjadi hidangan lezat. Kegiatan berkebun juga mampu menumbuhkan kecintaan anak terhadap sayuran tertentu yang sebelumnya tidak terlalu disukai oleh anak, misalnya bawang daun.

e. Menambah wawasan anak terkait nama-nama benda yang digunakan dalam kegiatan berkebun, nama-nama tanaman dan juga istilah-istilah lain yang dapat anak peroleh ketika melaksanakan kegiatan berkebun.

\section{Simpulan}

Berdasarkan hasil penelitian yang telah di paparkan sebelumnya, maka dapat disimpulkan bahwa kegiatan berkebun mampu meningkatkan keterampilan proses sains anak TK Lab. UPI, oleh karena itu kegiatan berkebun ini dapat dijadikan sebagai salah satu alternatif pembelajaran sains yang tepat dan sarana pengembangan berbagai aspek perkembangan bagi anak usia dini. 


\section{Daftar Pustaka}

Asiah. (2012). Kemampuan Sains Anak Usia Dini Melalui Pembelajaran dengan Keterampilan Proses dan Produk. Al-Fikrah: Jurnal Kependidikan Islam, 3 (1), hlm. 26-36.

Bosse. S, Jacobs. G, Anderson, T.L. (2009). Science in The Air. NAEYC.

Chaedar. (2010). Pokoknya Action Research. Bandung: PT Kiblat. Buku Utama.

Charlesworth, K \& Lind. (2010). Math and Science for Young Children. United States of America: WARDWORTH Cendage Learning.

Dahar, R.W. (1996). Teori-teori Belajar. Jakarta : Erlangga

Gross. C., M. (2012). Science Concepts Young Children Learn Through Water Play. Dimensions of Early Childhood Vol 40, No 2, 2012.

Halverson. K. (2007). Science in Early Childhood. Retrieved from www.uwlax.edu.

Kellough, Richar. D. (1996). Integrating Mathematic and Science For Kindergarten and Primary School. Collumbus, Ohio: Merril Prentice Hall.

Nugraha, Ali. (2008). Pengembangan Pembelajaran Sains Pada Anak Usia Dini. Bandung: JILSI Foundation.

Remaklus. U. (2014). Putting the Garden to Sleep: Understanding the Meaning of Nature. Voice of Practitioners, 9 (1), hlm. 1-20.

Sumaji. (1988). Psikologi Pendidikan. Jakarta: CV.Rajawali

Suyadi \& Ulfah. (2013). Konsep dasar PAUD. Bandung: PT. Remaja Rosdakarya.

Santrock, J. W. (2007). Perkembangan anak, Child development, eleventh edition, Jilid 1. Jakarta: Erlangga.

Thomas, J and Harden, A. (2007). Methods for the thematic synthesis of qualitative research in systematic reviews. London: Social Science Research Unit.

Trundle, Kathy. C. (2009). Teaching Science during the Eraly Childhood Years. National Geographic, Hampton Brown. 